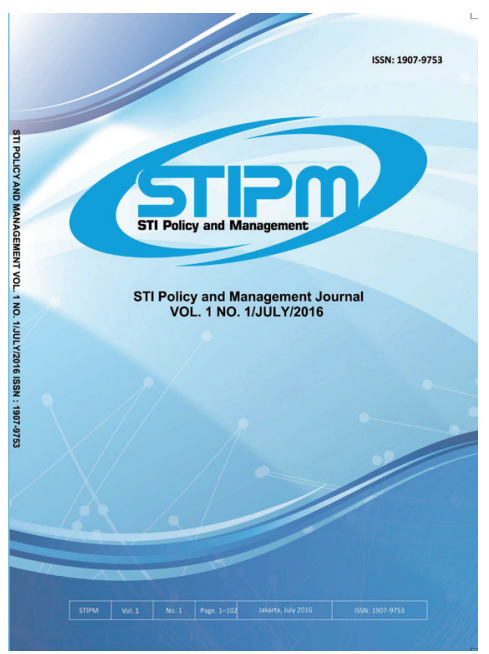

Journal of STI Policy and Management

Publication details, including instructions for authors and subscription information: http://www.stipmjournal.org/

\title{
Influential Factors of Evidence-Based Energy Policy-making: Government Regulation on Targeting Renewable Energy in Indonesia
}

\author{
Wati Hermawati, Prakoso Bhairawa Putera, Dudi Hidayat, \\ Ishelina Rosaira P. \\ Center for Science and Technology Development Studies, Indonesian \\ Institute of Sciences, Indonesia \\ Version of record first published: 15 July 2016
}

To cite this article: Hermawati, W., Putera, P.B., Hidayat, D. \& Rosaira P., I. (2016). Influential Factors of Evidence-Based Energy Policy-making: Government Regulation on Targeting Renewable Energy in Indonesia. Journal of STI Policy and Management, 1(1), 59-73

To link to this article: http://dx.doi.org/10.14203/stipm.v1i1

ISSN 1907-9753 (Print); ISSN 2502-5996 (online)

Accreditation Number: 622/AU3/P2MI-LIPI/03/2015

Full terms and conditions of use: https://creativecommons.org/licenses/by-nc-sa/4.0/

You are free to:

- Share $\quad$ : copy and redistribute the material in any medium or format

- Adapt : remix, transform, and build upon the material

- The licensor cannot revoke these freedoms as long as you follow the license terms.

Under the following terms:

Attribution - You must give appropriate credit, provide a link to the license, and indicate if changes were made. You may do so in any reasonable manner, but not in any way that suggests the licensor endorses you or your use.

NonCommercial - You may not use the material for commercial purposes.

ShareAlike - If you remix, transform, or build upon the material, you must distribute your contributions under the same license as the original.

No additional restrictions - You may not apply legal terms or technological measures that legally restrict others from doing anything the license permits.

Notices:

- You do not have to comply with the license for elements of the material in the public domain or where your use is permitted by an applicable exception or limitation.

- No warranties are given. The license may not give you all of the permissions necessary for your intended use. For example, other rights such as publicity, privacy, or moral rights may limit how you use the material.

- If you copy the dataset merely to extract the uncopyrightable data elements would not need permission to do so. However, if you republish the full dataset or using the copyrightable data layers require a permission from PAPPIPTEK-LIPI. 


\section{JOURNAL OF STI POLICY AND MANAGEMENT}

Volume 1 No. 1 July 2016

\section{LIST OF CONTENTS}

Innovation System Reform in Indonesia and Vietnam: A new Role for Universities?

Erik Baark.

Technology and Standardization Strategies related to the Diffusion of Smart Houses: The Case of ECHONET in Japan

Kumiko Miyazaki, Kentaro Nishida

Intellectual Property Creation of Japanese Companies in China and Thailand

Masayuki Kondo.

Technological Capability Upgrading and Entrepreneurship: Case Study of Selected Indonesian Fish Processing Companies

Erman Aminullah, Trina Fizzanty, Galuh S. Indraprahasta, and Indri J. Asmara

Influential Factors of Evidence-Based Energy Policy-making: Government Regulation on Targeting Renewable Energy in Indonesia

Wati Hermawati, Prakoso Bhairawa Putera, Dudi Hidayat, and Ishelina Rosaira P.

Finding the Most Efficient Technology Transfer Route Using Dijkstra Algorithm to Foster Innovation: The Case of Essential Oil Developments in the Research Center for Chemistry at the Indonesian Institute of Sciences

Arief A. R. Setiawan, Anny Sulaswatty, and Agus Haryono 


\title{
if STI POLICY AND MANAGEMENT

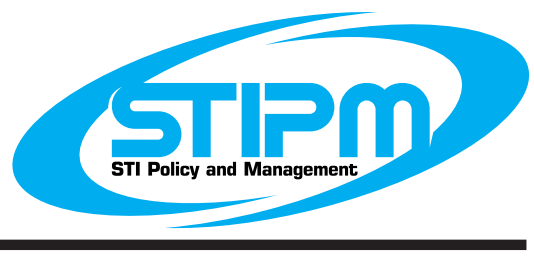

\section{Influential Factors of Evidence-Based Energy Policy-making: Government Regulation on Targeting Renewable Energy in Indonesia}

\author{
Wati Hermawatia , Prakoso Bhairawa Putera a, Dudi Hidayat ${ }^{\text {a }}$ Ishelina Rosaira P. ${ }^{\text {a }}$ \\ ${ }^{a}$ Center for Science and Technology Development Studies, Indonesian Institute of Sciences, Indonesia
}

\begin{tabular}{|c|c|}
\hline ARTICLE INFO & ABSTRACT \\
\hline Article History: & \multirow{17}{*}{$\begin{array}{l}\text { The paper is based on research identifying lessons and approaches in } \\
\text { making energy policy and scrutinizes whether empirical evidence-based } \\
\text { energy policy exists in Indonesia. Empirical evidence-based energy } \\
\text { policy has the potential to reduce poverty as well as have a greater } \\
\text { impact on the economic performance of individuals, communities and } \\
\text { the government. In this study, we used document analysis and key } \\
\text { informant interviews to explore empirical evidence input in energy } \\
\text { policy-making. The results of the analysis revealed the following } \\
\text { three points. First, there are a range of limitations in the process of } \\
\text { energy policy-making as well as in getting an evidence inputs from } \\
\text { concerned institutions such as universities, R\&D institutions, and } \\
\text { industries. Second, the process in making energy policy went through } \\
\text { several stages and was not always in sequences, starting from problem } \\
\text { identification, needs identification, advocacy, information gathering, } \\
\text { policy drafting, and approval obtainment from the institutions } \\
\text { concerned. Third, the most influential factor in the formulation of this } \\
\text { energy policy is the factor of power and authority instead of knowledge } \\
\text { and evidence. The limitations have demonstrated insufficient evidence } \\
\text { in the policy-making. Finally, the paper suggests that a working group } \\
\text { for data and information gathering should be created. }\end{array}$} \\
\hline Received : 29 January 2016 & \\
\hline Revised : 21 June 2016 & \\
\hline Accepted : 21 June 2016 & \\
\hline Available online : 15 July 2016 & \\
\hline Keywords: & \\
\hline Evidence-based policy & \\
\hline Renewable energy & \\
\hline Policy formulation & \\
\hline Influential factors & \\
\hline & \\
\hline & \\
\hline & \\
\hline & \\
\hline & \\
\hline & \\
\hline & \\
\hline
\end{tabular}

C2016 PAPPIPTEK-LIPI All rights reserved

\section{INTRODUCTION}

\section{A. Background and objectives}

Indonesia still has a high dependence (95\%) on fossil fuels in the fulfillment of its total energy consumption, powered by oil (46\%), coal (31\%) and natural gas (18\%) (Pusdatin ESDM, 2014).

\footnotetext{
* Corresponding Author. Tel: +62 81314134000

E-mail: wherma2007@yahoo.com
}

The high reliance on fossil fuels causes vulnerabilities in energy security and simultaneously increases government subsidies that have not been followed by economical behavior in energy use by the public. The relatively inexpensive prices for energy (especially fuel and electricity) compared to other countries also causes people to be wasteful in energy use. Therefore, ensuring energy security has been a central mission of the Indonesian government today. While 
energy supply security remains important, energy security policies must address all energy sources, including new and renewable energy, and consider infrastructure, service and economic issues.

Research by various experts and scientists as well as the experiences of various developed countries show that fuel and electricity can be produced from a variety of natural, renewable resources (El Bassam, 2010; Johansson, Kelly, Reddy, \& Williams, 1993). These renewable energy sources, which hold potential for and are quite abundant in Indonesia, include biomass, geothermal, micro-hydro, and solar. Biomass can be produced for bio-ethanol and bio-diesel, which can replace petrol and diesel. Biomass can also be used to generate electricity, such as by using gasification technology (Hermawati, Mahmud, Grace, \& Rosaira, 2010; Hermawati, Mahmudi, Maulana, Rosaira, \& Alamsyah, 2013; Abimanyu \& Sunith, 2014). These renewable energy sources, if properly managed, will be sustainable (Lubis, 2007). Almost all of these have also been used to generate energy in many developed countries such as Finland, Germany, USA, UK, and even developing countries like India and China (Hermawati et al., 2013; Abnisa, Daud, Husin \& Sahu, 2011; Aguilar, Song \& Shiftley, 2011; DECC, 2009).

Determining renewable energy targets in policy documents, such as laws, regulations and guidelines, could have a profound effect on the future availability of energy for citizens and the national development. There have been attempts by the government of Indonesia to maximize the utilization of renewable energy, with the aim to boost renewable energy use from 5\% in 2013 to $23 \%$ in 2025 and at least $31 \%$ by 2050 , as long as demands of the economy have been met (KEN Article 9, point $\mathrm{f}(1)$ ). These targets have been set out in the National Energy Policy (KEN), specifically in Government Regulation (PP) No. 79/2014. Achieving them requires the right strategy and support from all stakeholders of energy.

Target-setting in a policy document is not baseless. The policy, according to Adisasmito (2013, p. 19), does not only draw upon legal substance, but also on evidence-based studies. This interesting point has been selected as the subject for analysis in this study. The characteristics of the basis on evidence can be identified from the policymaking process. Young \& Quinn (2002) observe that the policy cycle can be divided into six stages; this is in line with Stover \& Johnston (1999), affirming that basis on evidence can be identified in the early processes of policy-making, especially in the stage of problem identification, needs recognition, and information collection.

Studies directly related to empirical and evidence-based policy in the energy sector, particularly in Indonesia, have not been frequently found in a variety of media, such as scientific journals, research reports, magazines and ejournals. A mapping of a number of studies on energy policy undertaken in Indonesia shows that the majority of research is related to the implementation and evaluation of energy policy both at macro and micro levels (Suherman, 2009; Sunarjanto, Suprijatno, Isnawati \& Riyanto, 2009; Sadirsan, Siregar, Eriyatno \& Legowo, 2014; Putera \& Gustina, 2014; Triatmojo, 2013).

In this paper we elaborate on the process of energy policy-making. First, by understanding the process of drafting a national energy policy, it can be found whether empirical evidence influences and becomes the basis for policy-setting, and what involvement of actors there is in the policy-making process. Second, what is the most influential factor in the formulation of energy policy? Is there other factor besides scientific knowledge and evidence? In addition, the study also provides recommendations for improvement for stages of process so far undertaken by the National Energy Board (DEN), the leading actor in preparing National Energy Policy (KEN), so that the KEN produced can be better.

\section{B. Methodology}

This study is an effort to improve the process of energy policy formulation in Indonesia, particularly on renewable energy. Using the case of Government Regulation (PP) No. 79/2014, we interviewed the members of DEN (twelve experts) involved in the policy formulation from March 2015 to September 2015. Documents of the policy-making process, such as reports of 


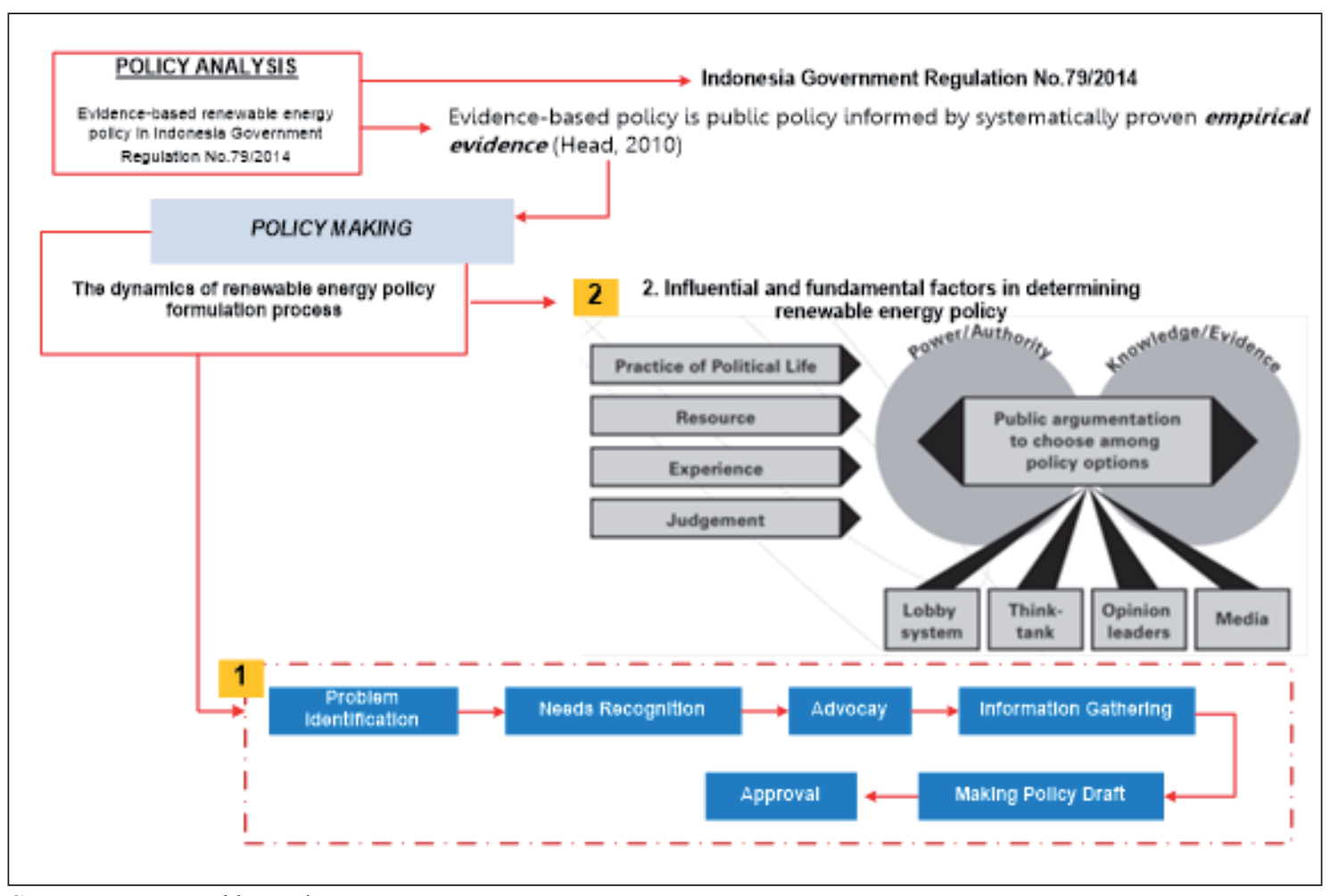

Source: constructed by authors

Figure 1. Analytical Framework of Renewable Energy Policy Formulation Process

meetings/assembly, monthly and semi-annual progress reports, final reports, press releases, as well as newspaper clippings and other media have been used as sources of data for this study.

Analysis of the interviews and of the content of PP No. 79/2014 is used to determine whether or not any empirical evidence is used in the policy formulation. The process of analysis uses the following framework in Figure 1.

Figure 1 explains the six stages of the policy formulation using a concept popularized by Stover \& Johnston (1999). The stages start from problem identification, to needs recognition, advocacy, information collection, drafting, and finally to approval. By revealing the dynamics of the drafting process, factors that influence and become the basis for setting the policy can be identified. The factors will be in line with a concept proposed by Segone (2008) which focuses on two main influencing factors, namely power and knowledge. By applying this framework, we are able to learn the dynamics of the renewable energy policy formulation process in Indonesia as well as the activities within the policy formulation stages.
As we need to describe the dynamics of the policymaking process, the study assumes an interpretivist paradigm in analyzing the whole process of policymaking and identifying its influential factors. The selected interpretative approach is especially well-suited because of its focus on the nature of the subject of social world and seeks to understand it from the framework of the research object. Interpretivism is a way to understand and explain social world through the spectacles of the actors involved.

\section{LITERATURE REVIEW}

Many countries seek to implement the concept of sustainable development, the type of development that seeks to meet the needs of the present without compromising the ability of future generations to meet their own needs (UNEP/IEA, 2002). One prerequisite for the creation of sustainable development is the availability of sufficient and sustainable energy, as energy is directly correlated with economic and social development as well as improvement of the local Human Development Index (UNDP, 2010). 
As in other countries, in Indonesia, renewable energy-related research is mostly conducted by technological experts and mostly surrounding its implementation in comparison with specific studies discussing evidence-based energy policy. Research on energy policy is generally related to the policy implementation, including the development of renewable energy and the paradigm shift occurring at the national level (Park, 2014; Triatmojo, 2013; Mufrizon \& Purwo, 2013; Sugiyono, 2004).

Results of several studies on energy policy regarding energy efficiency policies, policies in technology transfer, and the role of researchers in decision-making have also been published by various international publications (Eckman \& Paul, 2010; Sorell, 2007; Pettifor, Wilson \& Chryssichoidis, 2015; Zhi, Su, Ru \& Anadon, 2013; Dastan, 2011; Behague, Tawiah, Rosato, Some \& Morrison, 2009;). Thorough discussions surrounding the evidence-based policy were carried out by experts in the health sector (Jacobs et al., 2012; Anderson et al., 2005; Orton, Lloyd-Williams, Taylor-Robinson, O'Flaherty \& Capewell, 2011; Flitcroft, Gillespie, Sarkeld, Carter \& Trevena, 2011).

The complexity of policy formulation in the health sector has similarities with the energy sector, as policy formulation in both sectors is highly dependent on a number of indicators of science and technology, as well as economic, social, and political pressure (Rutten, Luschen \& von Lengerke, 2003; Flitcroft et al., 2011; Triatmojo, 2013). Several experts stress that the decision-making elements of the policy process must be based on evidence, including scientific evidence or research results (Sutton, 1999; Zardo $\&$ Collie, 2014). The use of empirical evidence was found to reduce uncertainty and risk that possibly resulted from decision-making (Bulmer, Dolowitz, Humphreys \& Padgett, 2007).

At the international level, research on renewable energy policy is more associated with technological innovation. One of the research projects on technological innovation was based on patents calculated in 25 countries in 26 years shows that public policy, particularly the energy sector, can trigger the growth of energy patent applications (Johnstone, Hašcic \& Popp, 2010). Meanwhile, Sharman and Holmes (2010) discuss the EU mandate in 2009, given directly to member countries, to use renewable energy (biofuel) for $10 \%$ of the transport fuel domestically until 2020. Nevertheless, much scientific research in the EU question the ability of biofuel in reducing greenhouse gas emissions (GHG) while criticizing the political motivation in implementing these targets, arguing that the politically motivated $10 \%$ target rather should be have been based on the results of scientific studies. Sorell (2007) specifically discusses the role of systematic reviews in improving evidence-based policy in the energy sector in the UK. Systematic reviews as a method has several advantages and disadvantages when applied to the study of evidence-based policy, especially if the policy scope is notably broad.

\section{RESULTS}

\section{A. The Milestone of National Energy Policy Formulation}

The initiative to formulate a National Energy Policy (KEN) was based on the mandate in the law PP No. 30/2007, which concerns energy. In substance the regulation contains a basic policy on the availability of energy for national needs, priorities of energy development, utilization of national energy resources, and national energy buffer reserves.

The idea of drafting a national energy policy in Indonesia did not come for the first time between 2009 and 2014. The drafting of a national energy policy also cannot be separated from events in the mid-1970s, when an energy crisis developed in parts of the United States as a result of the Gulf War. This problem echoed to Indonesia. Responding to the event, a number of figures in the field of energy in Indonesia began to discuss domestic energy problems conceptually. In 1976, the State Minister of Research formed an Energy Resources Technical Committee (PTE), a part of the Natural Resources Committee. Its task is to identify the various problems in the field of energy resources. Various issues discussed at PTE often faced difficulties in being translated into decisions; therefore, members of the PTE con- 
sidered the need for a "body" on a higher level, thus capable of making decisions and national policy in the field of energy (Soegiarto, Iswanti \& Asihanti, 2007).

The Directorate of Energy, Minerals and Mining Resources at the Ministry of Energy and Mineral Resources and the National Development Planning Agency (2012) noted that the idea of a national energy policy first appeared in 1976. At that time, the aim of energy policy was to maximize the utilization of energy resources. In order to make the drafting of energy policies effective, the government established the National Energy Coordinating Agency (BAKOREN), a state agency equal to a department level, responsible for formulating energy policy and coordinating the implementation of the policies. As an institution, it was similar to the National Energy Board in the present.

The work of BAKOREN was demonstrated by its issuance of the Common Policy on Energy (KUBE) in 1981. KUBE 1981 focused on energy intensification, diversification, conservation and indexation. Intensification efforts were made through increased surveys and explorations for resources to economically determine energy potential. Diversification was an attempt to diversify the use of non-petroleum energy through reducing oil use and setting coal as the primary fuel for power plants and the cement industry. Conservation was done through the use of more efficient plant equipment and energy user appliances. KUBE 1981 is equipped with three supporting policies (research and development, the energy industry and investment climate.

In line with economic development and changing dynamics, KUBE was revised in 1987 and 1991. The 1987 and 1991 KUBE focused on energy intensification, diversification, and conservation with the support of three other policies (the energy industry, investment climate and the price of energy). The $1991 \mathrm{KUBE}$ had been concerned with environmental issues; it was the result of industrialization processes which caused environmental damage. Therefore, energy policy began to be directed to the use of more environmentally friendly, renewable energy.
In 1998, KUBE was re-established with the aim to create a climate which would support the achievement of energy sector development strategy and provide certainty for economic actors in connection with the procurement, supply and use of energy. At KUBE 1998, the issue of energy resource limitations began to emerge, particularly for oil. Petroleum was gradually directed for domestic use as fuel and raw material of industries capable of increasing high added value. The energy policy to be implemented included five main policies (diversification, intensification, conservation, the average pricing of energy, and environmental aspects) and nine supporting policies (increasing investment, provision of incentives and disincentives, standardization and certification, development of infrastructure, human resources quality improvement, management of information systems, research and development, as well as institutional development and regulation).

At the end of 2003, the Ministry of Energy and Mineral Resources (MEMR) issued a new KEN and the Renewable Energy Development and Energy Conservation (Green Energy) Policy. The policy was a renewal of 1998 KUBE, whose drafting was carried out together with stakeholders of energy. In addition, the policy also became the main reference in composing the draft of the Law on Energy, which was just being prepared. The main objective of the formulation of KEN 2003 is to create sustainable national energy security in supply and efficient use of national energy. To that end, the dependence on one particular type of energy sources must be continually reduced by optimizing the utilization of alternative energy sources, especially renewable ones, and by increasing the efficient use of energy technology. In KEN 2003, the fulfillment of domestic energy became a top priority and regional empowerment in energy management was to be improved.

In 2006, Presidential Decree No. 5 of 2006 on KEN was issued as a guideline for national energy management. The main policies of KEN 2006 were: (i) provision of energy through guaranteeing the domestic energy supply availability, optimizing domestic production and implementing energy conservation; (ii) utilization of en- 
ergy through energy use efficiency and energy diversification; (iii) directing energy price policy economically, taking into account the ability of small businesses and aid for the underprivileged; and (d) environmental preservation by applying the principles of sustainable development. The supporting policies cover infrastructure development, government and business partnerships, community empowerment and development of $\mathrm{R} \& \mathrm{D}$, including training.

Although the process of drafting energy policy experiences improvements from time to time, there are still many contradictions in the policy materials. Interviews with the Directorate of Energy, Minerals and Mining Resources and the National Development Planning Agency (2012) revealed that energy development strategies, both short-term and long-term, were unclearly structured. The existing policies seem to be partial policies with no strategic flow in long-term programs. The milestones of National Energy Policy Formulation 1975-2014 are presented in Figure 2.

\section{B. The Process of Policy Formulation}

The drafting of renewable energy policy in Indonesia, contained in PP No. 79/2014, cannot be separated from the process of national energy policy formulation in 2014. This is because the renewable energy policy becomes part of the national energy policy. There are 10 articles in the PP No.79/2014 related to the renewable energy policy (see Table 1).

The drafting of KEN 2014 was started in 2008, with the establishment of the National Energy Board (DEN) through Residential Decree No. 26 of 2008; member composition of DEN consists of:

1. a governmental element, which includes Ministers or other government officials and is directly responsible for the provision, transportation, distribution, and utilization of energy. The seven ministers/officials are a) the Minister of Finance, b) the State Minister of National Development Planning/Head of Bappenas, c) the Minister of Transportation, d) Minister of Industry, e) the Minister of Agriculture, f) State Minister for Research and Technology, and g) the State Minister of Environment; and

2. a stakeholder element. There are eight DEN members of the stakeholder element: two from an academic background, two from the industry, two from consumer groups, one from a background in technology, one from a background in environment, as well

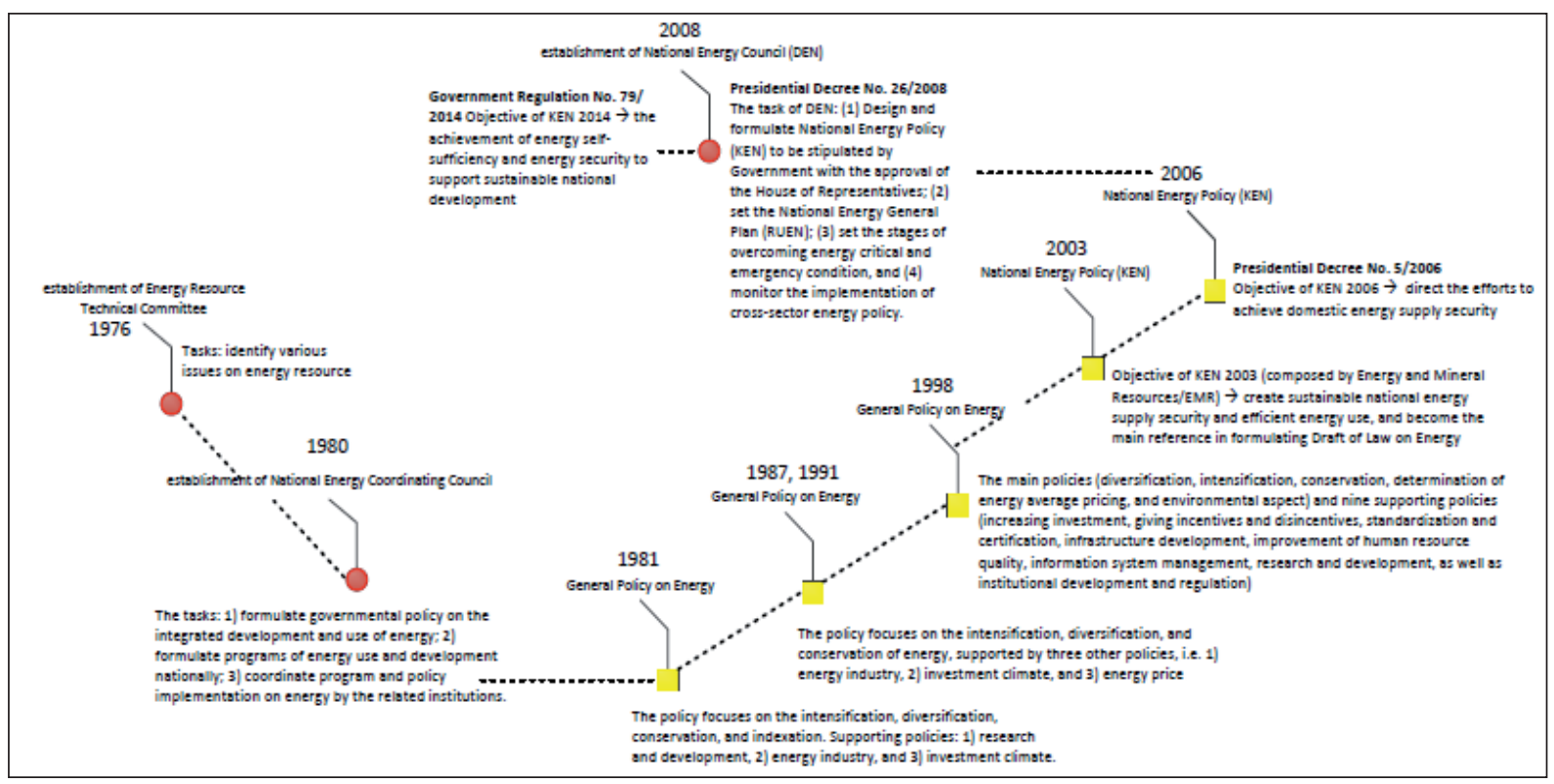

Source: Authors

Figure 2. Milestones of National Energy Policy formulation 1975-2014 
Table 1.

Regulation Concerning Renewable Energy Policy in Indonesia in PP No. 79/2014

\begin{tabular}{|c|c|}
\hline Article/Paragraph & Points \\
\hline Article 9 & Section (f), the achievement of optimum primary energy mix \\
\hline \multirow[t]{2}{*}{ Article 10 Paragraph (1) } & $\begin{array}{l}\text { Section (a), the improvement of resources exploration, potential and/or } \\
\text { proven reserve of energy }\end{array}$ \\
\hline & $\begin{array}{l}\text { Section (f), ensuring the security of the carrying capacity of the } \\
\text { Environment to ensure the availability of water and geothermal energy } \\
\text { resources. }\end{array}$ \\
\hline Article 11 Paragraph (2) & $\begin{array}{l}\text { Section (a) the actualization the economical balance of energy priorities } \\
\text { of national energy development, based on the principle of maximizing the } \\
\text { use of renewable energy by paying attention to economical level. }\end{array}$ \\
\hline Article 12 Paragraph (1) & $\begin{array}{l}\text { The use of national energy resources is performed by the Government and/ } \\
\text { or Local Government referring to certain strategies. }\end{array}$ \\
\hline Article 18 Paragraph (2) & $\begin{array}{l}\text { Section (b), energy diversification is performed at the very least through: } \\
\text { acceleration of provision and utilization various new and renewable } \\
\text { energy resources. }\end{array}$ \\
\hline Article 20 Paragraph (2); (4); (5) & Assumption of renewable energy price calculation. \\
\hline Article 21 & $\begin{array}{l}\text { Subsidies in certain cases are provided by the government and local } \\
\text { government, given that (as in Section (b)) renewable rnergy prices (as } \\
\text { referred to in Article 20, Paragraph (2)b) is more expensive than the price } \\
\text { of energy from fossil fuels that is not subsidized. }\end{array}$ \\
\hline Article 22 & $\begin{array}{l}\text { National and local government provide fiscal and non-fiscal incentives to } \\
\text { encourage programs of energy source diversification and renewable energy } \\
\text { development. }\end{array}$ \\
\hline Article 23 Paragraph (2) & $\begin{array}{l}\text { Section }(d) \text {, the acceleration of the provision of new and renewable energy } \\
\text { infrastructure. }\end{array}$ \\
\hline Article 24 Paragraph (2) & $\begin{array}{l}\text { Section (b), strengthening the development of the energy industry through } \\
\text { increasing the production equipment industry development and utilizing } \\
\text { domestic renewable energy. }\end{array}$ \\
\hline
\end{tabular}

Source: PP No. 79/2014 on National Energy Policy

as others selected by the House of Representatives (DPR-RI) through a feasibility test upon a proposal from the government. DEN members of the stakeholder element are appointed through Presidential Decree Number 17/P of 2009. With the formation of DEN, comprising of both the government and stakeholders, the planning of KEN began as the main task. In implementing KEN drafting, DEN was assisted by a technical organ under the Secretariat-General of DEN, namely the Bureau of Energy Policy Facilitation and Assembly. The stages in drafting KEN 2014 were not carried out in sequence; some stages were performed simultaneously. While six stages were identified by Young and Quinn (2002), in KEN 2014 they were grouped into three stages as follows:

\section{Problem identification}

At KEN 2014, this stage was initiated by the government as part of the tasks mandated by the 2009 Energy Law. DEN's procedure in drafting KEN 2014 started with the preparation of materials and information related to energy management conditions both nationally and locally. This was done to obtain sufficient problem identification related to the field of energy.

To sharpen the task of formulating the policy, the DEN Working Group (Pokja DEN) was formed through Minister of Energy and Mineral Resources Regulation No. 20 of 2009 to prepare the basic materials and compose the initial draft of KEN. The establishment of the working group was the result of the second Assembly of DEN members on 21 August 2009. The results of the Assembly also authorized the composition the Term of Reference (TOR) of the Academic Paper of KEN Draft (R-KEN). 


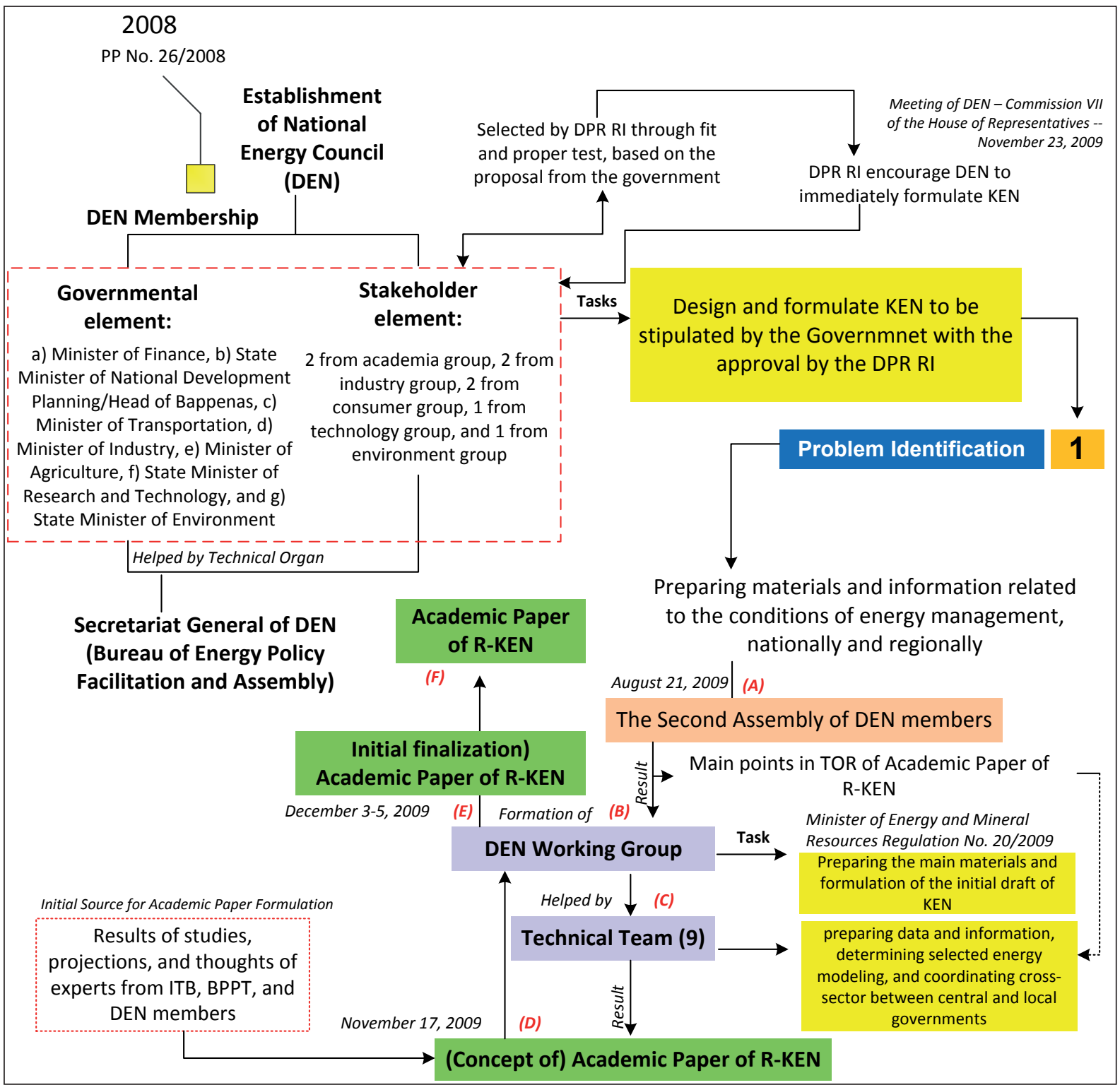

Source: Authors

Figure 3. Stages of problem identification in the formulation of KEN

The terms in R-KEN were the result of discussions held by DEN members from the stakeholder element, the permanent representative of DEN members from the government element and various other stakeholders. The main focus of the TOR was a view of the paradigm shift in perceiving energy resources - no longer as a commodity to generate foreign exchange, but as development capital. Furthermore, Pokja DEN worked with the assistance of the technical team, which was composed of Group A to Group I (based on the issues and subject matter discussed in R-KEN). The tasks of the technical team in
Pokja DEN were preparing data and information, determining the selected energy modeling, and coordinating across sectors between the center and regions. The stages of problem identification in the formulation of KEN are as it appears in Figure 2.

In its data and information collection, the technical team did not have a thorough data collection mechanism that was capable of accommodating all the results of research conducted by energy stakeholders, such as the R\&D department of Energy and Mineral Resources (EMR), Bandung Institute of Technology (ITB), (Agency for 
Technology Assessment and Application) (BPPT) and universities, as well as industry. Most of the data and information were obtained from BPPT and the Research Center for Geology at the Ministry of Energy and Mineral Resources (MEMR), and were used to formulate the policy. Some of the data and information required to complement the policy-making was provided by members of DEN. There was no comprehensive data collection mechanism which involved all the relevant stakeholders. It was the working results of this team that were used as material by Pokja DEN to finalize the Academic Paper and to report to DEN members through the meeting. The end result of this stage was an Academic Paper which was then used as the basis for composing the draft of KEN.

What was done in the initial process of drafting KEN is different from the six-stage model discussed previously. Stover \& Johnston (1999) propose that the early stages (problem identification) are commonly initiated by technocrats (including scientists, academics, researchers and other experts) who provide information to identify the coverage/scope and basic problems as well as analytical techniques of the causes and solutions. They also gather and analyze data and present them in various forms to illustrate the current and future issues. However, in the formulation of KEN, it was initiated and driven by the tasks assigned to DEN as mandated by the 2009 Energy Law, as well as by the insistence of Commission VII of the House of Representatives to immediately prepare KEN. Technocrats were asked to give views on the formulation of the initial draft of KEN Academic Paper by each technical team in accordance with the issues and subject matter in the TOR.

2. Needs Recognition, advocacy and information gathering

The Academic Paper that had been approved was then used as reference material for the drafting of R-KEN. However, in order to obtain a more comprehensive input, DEN members of the stakeholder element, supported by the SecretaryGeneral of DEN, conducted an input-netting process to recognize user needs in energy policy. The process was done through consultation, coordination, discussion and socialization with various government agencies, central and regional institutions, the Presidential Advisory Council (Watimpres), universities, R\&D institutions, associations and non-governmental institutions. Along with recognition of needs, advocacy was carried out toward Members of Parliament, as well as information collection through studying energy policies in other countries.

The process of netting the needs emphasized on efforts to obtain inputs on the direction of energy policy to keep in line with the 1945 Constitution and the Energy Law, and also to avoid contradiction with other legislation. During this stage, members of DEN obtained inputs regarding the projected demand and supply of energy in Indonesia from experts at BPPT and ITB. The prepared projection was then reviewed by members of DEN, later appearing in the RKEN draft. It was the result of the review of DEN members, with data processing using Markal energy method.

Consistent with the needs recognition process, the DEN Working Meeting was conducted with Commission VII of the House of Representatives on January 20, 2010, in which Commission VII of the House of Representatives urged DEN to review the main points of the policy in the initial draft of KEN and to immediately accelerate its completion. The results of the working meeting with the House of Representatives became material for the Fourth Assembly of DEN Members (March 19, 2010), producing a note that the projected energy needs, energy mix and the main points of the policy that had been generated would need to be further explored to get an overview concerning the construction of nuclear power plants. It was advised to hold indepth discussions with a number of people and carry out comparisons with other countries such as Malaysia, Singapore and China.

The initial draft of R-KEN (Academic Paper) was then submitted in a meeting with Commission VII of the House of Representatives (19 April 2010). There were a number of notes to: (i) encourage efforts to optimize KEN in energy infrastructure development; (ii) establish a team for the development of nuclear power plants in Indonesia; and (iii) work for energy sector in- 
dependence and the development of alternative energies.

Throughout 2010-2011, discussion and refinement of R-KEN were intensively carried out involving not only the Parliament, but also consultation with the Vice President (June 24, 2010), Watimpres (September 6, 2010 and December 29, 2010) and the National Innovation Committee. The completed KEN material was received by the Vice President as the Vice Chairman of DEN on March 22, 2011; the KEN drafting material to be formulated was in the form of a draft Presidential Decree consisting of four chapters: (i) Introduction; (ii) Projected Needs; (iii) Projected Energy Supply and Mix; and (iv) points of KEN.

\section{Drafting KEN and the approval}

Toward the beginning of 2012, the discussion of the R-KEN draft reached the final stage and was to be submitted to the Seventh Assembly of DEN Members (January 11, 2012). The results of the Assembly, in the form of KEN drafting material, were then taken to the Plenary Session of DEN (March 8, 2012) that was led by the President as Chairman of DEN. At the Plenary Session a number of notes appeared, namely: (i) that RKEN should pay attention to the national, global and specific context, and pay attention to the short-, medium-, and long-term perspectives; (ii) that R-KEN should be packaged with the national strategic plan, in a similar time dimension with the MP3EI (the Master Plan for the Acceleration and Expansion of Indonesia's Economic Development), be realistic and take into account global factors beyond the outreach; (iii) that whenever possible, R-KEN should be made into legislation to make it more authoritative and provide certainty; and (iv) the energy mix needs to adjust the 2020 emission reduction targets by $26 \%$. Furthermore, the R-KEN was drafted in the form of Presidential Decree Draft (R-Perpres) on KEN. The proposal regarding translating the R-KEN into legislation could not be met as Article 11, Paragraph (2) of the Energy Law states that KEN was set by the government with the approval of the Parliament; thus the choices made were through the Presidential Decree on KEN. The process of R-Perpres formulation of KEN was conducted by the Secretariat-General of DEN. After the president had approved the substance of R-KEN, it was delivered to the Parliament.

The letter from the Chairman of DEN was then followed up with a meeting with Commission VII of the House of Representatives (August $28,2013)$, which resulted in an agreement to receive R-KEN for further discussion in the Working Committee (Panja) of KEN of Commission VII of the House of Representatives. In this development, R-KEN, originally proposed as R-Perpres on KEN, was approved as a Government Regulation draft (R-PP). This was decided by the Working Committee who perceived KEN as a strategic policy, thus needing a regulationstrengthening in the form of a PP (Meeting on December 11, 2013). Additionally, the points regarding nuclear energy in KEN still required further discussion (Meeting on December 16, 2013). However, the Commission VII of the House of Representatives finally approved KEN in the form of a Government Regulation with a note that nuclear energy was included in the National Energy General Draft (RUEN) (Meeting on January 21, 2014). These results were then sent to the Plenary Session with the House of Representatives on January 28, 2014, and approved by the House of Representatives as PP KEN. The new PP KEN was stipulated by the government on October 17, 2014. There was a relatively long time span from the approval by the Parliament to the stipulation by the government. This was due to the change in the form of regulations, having originally been planned in the form of Presidential Decree. This causes the need to readjust the formal regulation, hence requiring a relatively long time.

\section{DISCUSSION}

This case study illustrates the stages in the entire process of energy policy-making in Indonesia in general. Incorporating empirical evidence derived from results of studies or research from various $R \& D$ institutions or universities into the formulation of a policy is not easy or common in Indonesia. On one hand, for R\&D institutions and universities, research and study results are not targeted towards policy. On the other hand, the 


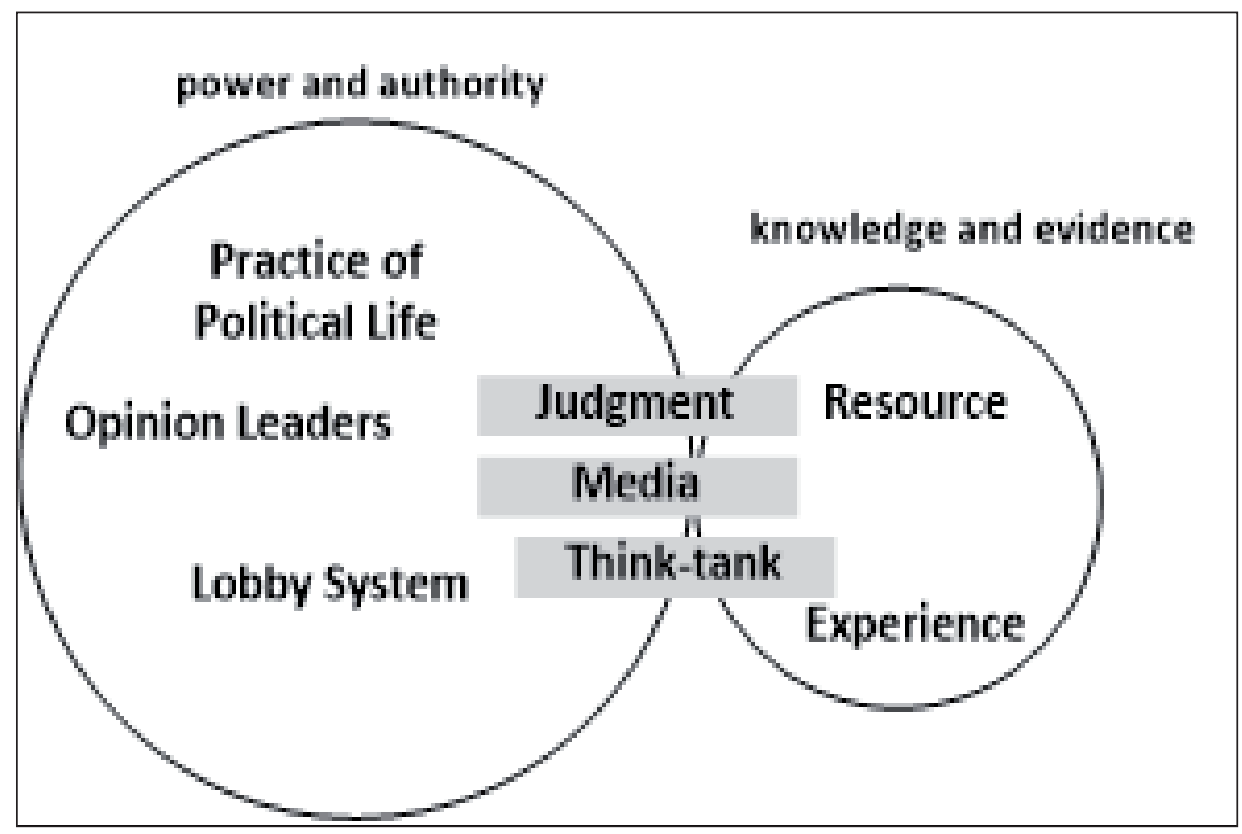

Source: Segone (2008)

Figure 4. Influential factors in the process of national energy policy formulation in Indonesia

mechanisms and communication between policymakers and implementers of research activities on energy are not well-established. In fact, the working groups set up to help DEN had not been able to gather empirical evidence produced by a variety of institutions and experts in Indonesia. The lack of participation of various institutions in providing input in the form of empirical evidence in the policy formulation process causes the resulting policy to be criticized and questioned.

Judging from influential factors, Segone (2008) states that there are two main factors influencing the formulation of a policy, namely power and knowledge (Figure 4). In the process of drafting KEN in Indonesia, power and authority as a factor is dominantly influential; it is characterized by the emergence of KEN as part of the mandate/provisions of the Law on Energy. It is in the context of power, therefore, that KEN must inevitably be formulated; this can be seen from the encouragement of the Parliament through Commission VII to immediately publish KEN since the beginning. Both of these are forms of direct intervention in the practice of political life. In addition, any discussion on KEN always involved the Parliament; each process went through the mechanism of working meetings.
Furthermore, KEN is strong with opinion leaders; it is seen in the directives of the President in the Plenary Session charging KEN, if possible, to be made into legislation to make it more authoritative and provide certainty, and the energy mix needs to adjust the 2020 emission reduction targets by $26 \%$. This is considered the political view and attitude of the leader.

KEN also has a strong lobby system. Where initially KEN was proposed as a Presidential Decree (Perpres), political forces and the strong encouragement of the House of Representatives, transformed KEN into a Government Regulation (PP). This indicates the strength of the lobby system, run by the House of Representatives to encourage the strengthening of energy regulation, not only in form of Perpres but in the form of PP.

\section{CONCLUSION}

Through the mandate of the Law on Energy No. 30 of 2007, the government formed the National Energy Council (DEN). DEN then conducted the process of energy policy-making (PP No. 79/2014) with the approval of the Parliament. Among some of the findings from this study of the energy policy-making process (PP 79/2014) that can be inputs for the government, especially 
energy-related institutions (Ministry of Energy and Mineral Resources and DEN), are:

1. The empirical evidence as a result of research and studies undertaken by various institutions and experts was not fully used as input in the process of energy policy making by DEN. In addition to the underdeveloped data collection mechanisms and research result information, DEN also had not established good communication with researchers. The representation of professionalism and institutions in DEN (academia, technology, society, industry groups) does not guarantee the creation of open communication and the availability of empirical data for the benefit of policy formulation.

2. The six stages in the implementation of energy policy-making were not conducted sequentially. The process of policy-making was only conducted in three stages, in which more than one of the six activities could be included in one stage. The three stages were: (i) problem identification; (ii) needs recognition, advocacy, and information gathering; (iii) composing policy draft and approval by the Parliament.

3. The most influential factor in the formulation of this energy policy is the factor of power and authority, instead of knowledge and evidence. The emergence of KEN as part of the mandate/provisions of the Law on Energy made its establishment an inevitability, not to mention the encouragement from the Parliament through the Commission VII to immediately publish KEN. This is a form of direct intervention in the practice of political life. KEN was also strong with opinion leaders and in its lobby system, thus allowing the change of KEN from the original proposition of Perpres into the form of PP.

Several recommendations for a better process in the making of a national energy policy, as currently undertaken by the National Energy Board (DEN) as the leading actor of national energy policy, include:

1. Evidence-based policy can only be formulated if the process of policy formulation is based on scientific evidence. This requires supportive mechanisms and communication between policymakers and researchers, and the building of a data information mechanism for the research results of various energy-related institutions. The creation of a database for the results of research in the field of energy can be achieved under the Ministry of Research, Technology, and Higher Education, with the involvement of DEN and the Ministry of Energy and Mineral Resources.

2. In order to create a 'friendly policy' for all stakeholders, DEN should adopt a scientific evidence-based policy model.

\section{ACKNOWLEDGEMENTS}

This paper was based on research results funded by the Center for Science and Technology Development Studies, Indonesian Institute of Sciences (Pappiptek-LIPI) in 2015. Therefore, we are very grateful to Pappiptek-LIPI and also to all individual experts who has contributed to this research results, particularly to Dr. Tumiran, who served on the National Energy Council (DEN) I the period of 2010-2014 and 2015-2019, and Dr. Herman Darnel Ibrahim, a member of National Energy Council (DEN) in 2010-2014, who was willing to discuss and provide more data and information for this study. Our thanks also go to the reviewers of this article.

\section{REFERENCES}

Abimanyu, H. \& Sunith, H. (Eds.). (2014). Konversi biomassa untuk energi alternatif di Indonesia: Tinjauan sumber daya, teknologi, manajemen, dan kebijakan [Biomass conversion for alternative energy in Indonesia: A review of resources, technology, management and policy]. Jakarta: LIPI Press.

Abnisa, F., Wan Daud, W. M. A., Husin, W. N. W., \& Sahu, J. N. (2011). Utilization possibilities of palm shell as a source of biomass energy in Malaysia by producing bio-oil in pyrolysis process. Biomass and Bioenergy Journal, 35, 1863-1872. http://dx.doi.org/10.1016/j.biombioe.2011.01.033 
Adisasmito, W. (2013). Perancangan naskah akademik dan kebijakan kesehatan [Academic manuscript design and health policy]. Jakarta: Universitas Indonesia (UI-Press).

Aguilar X. F., Song, N., \& Shiftley, S. (2011). Review of consumption trends and public policies promoting woody biomass as an energy feedstock in the U.S. Biomass and Bioenergy, 35, 3708-3717. http://dx.doi.org/10.1016/j. biombioe.2011.05.029

Anderson, L. M., Brownson, R. C., Fullilove, M. T., Teutsch, S. M., Novick, L. F., Fielding, J., \& Land, G. H. (2005). Evidence-based public health policy and practice: Promises and limits. Am J Prev Med, 28(5), 226-230.

Behague, D., Tawiah, C., Rosato, M., Some, T., \& Morrison, J. (2009). Evidence-based policymaking: The implications of globally-applicable research for context-specific problem solving in developing countries. Social Science and Medicine, 69(2009), 1539-1546.

Brownson, R. C., Chriqui, J. F., \& Stamatakis, K. A. (2009a). Understanding evidence-based public health policy. American Journal of Public Health, 99(9), 1576-1583.

, Fielding, J. E., \& Maylahn, C. M. (2009b). Evidence-based public health: A fundamental concept for public health practice. Annu Rev Public Health, 30(1), 175-201.

Bulmer, S., Dolowitz, D., Humphreys, P., \& Padgett, S. (2007). Policy transfer in the European Union. London: Routledge.

Dastan, S. A. (2011). Analysing success of regulatory policy transfer: Evidence from Turkish energy markets. Energy Policy, 39(2011), 8116-8124. http://dx.doi.org/10.1016/j.enpol.2011.10.006

Department of Energy and Climate Change (DECC). (2009). First progress report on the promotion and use of energy from renewable sources for the United Kingdom: Article 22 of the Renewable Energy Directive 2009/28/EC. London: Department of Energy and Climate Change.

Eckman, R. S., \& Stackhouse, P. W., Jr. (2010). CEOS contributions to informing energy management and policy decision making using space-based Earth observations. Journal of Applied Energy, 90(2012), 206-210.

El Bassam, N. (2010). Handbook of bioenergy crops: A complete reference to species, development, and application. UK: Earthscan and MPG Books.
Flitcroft, K., Gillespie, J., Salkeld, G., Carter, S., \& Trevena, L. (2011). Getting evidence into policy: The need for deliberative strategies? Journal of Social Science and Medicine, 72(7), 1039-1046. http://dx.doi.org/10.1016/j. socscimed.2011.01.034

Hermawati, W., Mahmud T, Grace, N, \&Rosaira, I. (2010). Kajian implementasi dan pemanfaatan pembangkit listrik tenaga mini/mikrohidro (PLTMH) untuk peningkatan usaha produktif masyarakat pedesaan [A study of the implementation and utilization of mini/microhydro power plants (PLTMH) in increasing productive efforts of rural communities]. Jakarta: LIPI Press.

Hermawati, W., Mahmudi, Maulana, I, Rosaira, I., \& Alamsyah, P. (2013). Sumber daya biomassa: Potensi energi Indonesia yang terabaikan [Biomass energy resources: Indonesia's neglected energy potential]. Bogor: IPB Press.

Jacobs, A. J., Clayton, P. F., Dove, C., Funchess, T., Jones, E., Perveen, G., Brownson, R. C. (2012). A survey tool for measuring evidence-based decision making capacity in public health agencies. BMC Health Services Research, 12(57). Retrieved from http://www.biomedcentral.com/1472-6963/12/57. http://dx.doi. org/10.1186/1472-6963-12-57

Johansson, B. T., Kelly, H., Reddy, A. K. N., \& Williams, R. H. (Eds.). (1993). Renewable energy: Sources for fuels and electricity, USA: Island Press.

Johnstone, N., Hašcic, I., \& Popp, D. (2010). Renewable energy policies and technological innovation: Evidence based on patent counts. Journal of Environmental \& Resource Economics, 45, 133-155.

Lubis, A. (2007). Energi terbarukan dalam pembangunan berkelanjutan [Renewable energy in sustainable development]. Jurnal Teknologi dan Lingkungan, 8(2).

Muller, S., Brown, A., \& Olz, S. (2011). Renewable energy: Policy considerations for deploying renewables. Paris, France: International Energy Agency.

Ministry of New and Renewable Energy of India (MNRE). (2009). National policy on biofuels. New Delhi, India: Ministry of New and Renewable Energy. 
Mufrizon, E., \& Subekti, P. (2013). Kebijakan energy baru-terbarukan serta peluang pemanfaatan biogas dan biomasa limbah pengolahan kelapa sawit untuk pembangkit tenaga listrik di Provinsi Riau [Renewable energy policy and opportunities for utilization of biogas and palm oil processing biomass waste for power generation in the province of Riau]. Riau: Jurnal APTEK, 5(1).

Orton, L., Lloyd-Williams, F., Taylor-Robinson, D., O'Flaherty, M., \& Capewell, S. (2011). The use of research evidence in public health decision making processes: Systematic review. PLoS One, 6(7).

Putera, P. B., \& Gustina, A. (2014). Policy actions pemerintah terhadap pengembangan bioenergy nasional: Tinjauan kebijakan pasca pemberlakuan Undang-undang Nomor 30 Tahun 2007 tentang energi [Policy actions of the government toward the national bioenergy development: A review of policy post-enactment of Energy Law 30/2007]. In H. Abimanyu and S. Hendrana (Eds.), Konversi biomassa untuk energi alternatif di Indonesia: Tinjauan sumber daya, teknologi, manajemen, dan kebijakan. Jakarta: LIPI Press.

Pusdatin (Pusat Data dan Informasi), KESDM. (2014). Handbook of energy and economic statistics of Indonesia 2014 in Tumiran 2015. In Proceedings of Presentasi Sosialiasi Kebijakan Energi Nasional PP 79/2014, DEN, Manggala Wana Bhakti, Jakarta, 6 Mei 2015.

Pettifor, H., Wilson, C., \& Chryssochoidis, G. (2015). The appeal of the green deal: Empirical evidence for the influence of energy efficiency policy on renovating homeowners. Energy Policy, 79(2015), 161-176. http://dx.doi. org/10.1016/j.enpol.2015.01.015

Danang, R. A., Nugraha, C., \& Hendang Setyo R. (2013). Analisis kebijakan pengembangan industri bahan bakar nabati bioetanol dari ubi kayu dengan menggunakan pemodelan matematika [Analysis of industrial development policy surrounding bioethanol from cassava as biofuel using mathematical modeling]. Reka Integra, 1(1), 193-203.

Rutten, A., Luschen, G., \& von Lengerke, T. (2003). Determinants of health policy impact: A theoretical framework for policy analysis. Soz Praventivmed, 2003(48), 293-300.

Sadirsan, E. S., Siregar, H., Eriyatno, \& Legowo, E. H. (2014). Development model of renewable energy policy based on social forestry for sustainable biomass industry. Journal of $S \& T$ Policy and R\&D Management, 12(1), 17-32.
Sharman, A., \& Holmes, J. (2010). Evidence-based policy or policy-based evidence gathering? Biofuels, the EU and the 10\% target. Environmental Policy and Governance, 20(5), 309-321.

Sugiyono, A. (2004). Perubahan paradigm kebijakan energy menuju pembangunan yang berkelanjutan [Paradigm change in energy policy toward sustainable development]. Jakarta. Presented in the Seminar Akademik Tahunan Ekonomi I, Pascasarjana FEUI \& ISEI, 8-9 December 2004, Hotel Nikko.

Soegiarto, K. A., Iswanti, S., \& Asihanti R. 2007. Profesor Samaun Samadikun: Sang Petani Silikon Indonesia. Jakarta: LIPI Press.

Sunarjanto, D., Munadi, S., Isnawati, \& Riyanto, H. (2009). Alternatif penyusunan kembali kebijakan pengelolaan energi ramah lingkungan [Reformulating the management policy of green energy]. In Proceedings of Seminar Nasional Dies Emas ITB, 4-5 Maret 2009.

Sorrell, S. (2007). Improving the evidence base for energy policy: The role of systematic reviews. Journal of Energy Policy, 35(2007), 1858-1871.

Stover, J., \& Johnston, A. (1999). The art of policy formulation: Experiences from Africa in developing national HIV/AIDS policies. Policy Occasional Paper No. 3. Washington, DC: Policy Project.

Suherman, I. (2009). Masa kini dan masa depan batubara Indonesia [The present and future of Indonesian coal]. Prosiding Kolokium Pertambangan 2009 (pp. 55-69). Bandung: Pusat Penelitian dan Pengembangan Teknologi Mineral dan Batubara.

Segone, M. (2008). Evidence-based policy making and the role of monitoring and evaluation within the new aid environment. In M. Segone (Ed.), Bridging the gap: The role of monitoring and evaluation in Evidence-based policy making. Switzerland: UNICEF Regional Office for CEE/CIS.

Triatmojo, F. (2013). Dinamika kebijakan diversifkasi energi di Indonesia: Analisis kebijakan pengembangan energi terbarukan di Indonesia [Dynamics of energy diversification policy in Indonesia: Analysis of renewable energy development policy in Indonesia]. Jurnal Ilmiah Administrasi Publik dan Pembangunan, 4(2). ISSN: 2087-0825.

United Nations Development Programme (UNDP). (2010). Human Development Index. UNDP. 
United Nations Environment Programme (UNEP), and International Energy Agency (IEA). (2002). Reforming energy subsidies: Opportunities to contribute to the climate change agenda. Retrieved 14 April 2016 from http://www.unep. org/pdf/pressreleases/reforming_energy_subsidies.pdf

Park, Y. S. (2014). Implementasi kebijakan konservasi energi di Indonesia [Energy conservation policy implementation]. E-Journal Graduate Unpar, 1(1). ISSN: 2355-4266.

Young, E., \& Quinn, L. (2002). Writing effective public policy papers: A guide to policy advisers in Central and Eastern Europe. Budapest: LGI.
Zhi, Q., Su, J., Ru, P., \& Anadon, L. (2013). The evolution of China's National Energy R\&D Programs: The role of scientists in science and technology decision making. Energy Policy, 61(2013), 1568-1585. http://dx.doi. org/10.1016/j.enpol.2013.06.044

Zardo, P., \& Collie, A. (2014). Measuring use of research evidence in public health policy: a policy content analysis. BMC Public Health, 14, 496. http://dx.doi.org/10.1186/1471-2458$14-496$ 